proximal tubular reabsorption of sodium and water (Bell et al., 1964). However, the reduction in osmolar clearance would not be caused by an excess of vasopressin, and is most likely to have resulted from reduced glomerular filtration rate or increased proximal reabsorption of glomerular filtrate. Because of this reduction in osmolar clearance it is felt that vasopressin is unlikely to have played a major part in the impaired excretion of water.

The association of oedema and hypercapnia in chronic chest disease is well known. The presence of oedema indicates that there is retention of both sodium and water. Experimental work with dogs has shown that chronic hypercapnia does not result in sodium retention (Schwartz et al., 1965). Experiments in man lasting up to a few hours have also failed to show sodium retention in response to hypercapnia (Longson and Mills, 1953), and a water diuresis may even be produced (Barbour et al., 1953). All of these experiments, however, were with fully oxygenated and healthy lungs, and none therefore reproduced the state of chronic hypercapnia seen in clinical practice.

The present study shows that many patients with chronic chest disease have reduced excretion of both sodium and water after a water load and that the arterial $\mathrm{CO}_{2}$ tension is closely related to the handling of water. This association does not prove a causal relationship but must raise the possibility of a direct effect of $\mathrm{CO}_{2}$.

These observations are likely to be of relevance to the oedematous state in chronic respiratory disease. It is not possible to draw definite conclusions about the exact mechanism involved and further studies are in progress to determine the importance of proximal tubular function and of vasopressin in reducing the response to a water load.

We thank Dr. Neville Oswald for his encouragement and advice, Professor J. Landon and Dr. D. G. Gibson for helpful criticism, and the anaesthetic laboratory for the blood gas determinations. We are grateful to the postal workers at the London Chief Office who acted as controls.

\section{References}

Aber, G. M., Bayley, T. J., and Bishop, J. M. (1963). Clinical Science, $25,159$.

Aber, G. M., and Bishop, J. M. (1965). Clinical Science, 28, 511.

Barbour, A., Bull, G. M., Evans, B. M., Hughes Jones, N. C., and Logothetopoulos, J (1953). Clinical Science, 12 ,

Bell, N. H., Schedl, H. P., and Bartter, F. C. (1964). American fournal of Medicine, 36, 351.

Gibson, D. G., Marshall, J. C., and Lockey, E. (1970). British Heart Fournal, 32, 399 .

Levy, M. S., Power, M. H., and Kepler, E. J. (1946). Fournal of Clinical Endocrinology, 6, 607

Longson, D., and Mills, J. N. (1953). Fournal of Physiology, 122, 81.

Platts, M. M., Hammond, J. D. S., and Stuart-Harris, C. H. (1960). Quarterly fournal of Medicine, 29, 559.

Schedl, H. P., and Bartter, F. C. (1960). Fournal of Clinical Investigation, 39, 248.

Schwartz, W. B., Brackett, N. C., jun., and Cohen, J. J. (1965). Fournal of Clinical Investigation, 44, 291.

Stuart-Harris, C. H., MacKinnon, J., Hammond, J. D. S., and Smith, W. D. (1956). Quarterly fournal of Medicine, 25, 389.

Wade, O. L., and Bishop, J. M. (1962). Cardiac Output and Regional Blood Flow. Oxford, Blackwell Scientific.

White, A. G., Rubin, G., and Leiter, L. (1953). Fournal of Clinical Investigation, 32, 931 .

\title{
Cure of Lung Cancer from Incomplete Surgical Resection
}

\section{R. ABBEY SMITH}

British Medical fournal, 1971, 2, 503-505

\section{Summary}

Three patients with lung cancer have been cured by incomplete removal of the cancer, which has for 20 years been the policy of this unit when complete removal is not possible. In each patient residual cancer remained on the wall of the left atrial chamber of the heart at the end of an operation for pneumonectomy.

Incomplete removal of cancer may, as a rare event, cure the patient. When residual cancer remained on any mediastinal structure other than the atrium cure has not been seen, though progress of the cancer seems to be retarded in some patients.

\section{Introduction}

Spontaneous regression of cancer has been documented (Everson and Cole, 1966). Of 176 cases of possible spontaneous regression of cancer collected by these authors, only one was in the lung (Blades and McCorkle, 1954). In an addendum a further case of regression of lung cancer was added (Bell, Jesseph, and Leighton, 1964). Sufficient detail was presented to allow the reader to reach a conclusion.

Cardiothoracic Unit, Walsgrave Hospital, Coventry

R. ABBEY SMITH, CH.M., P.R.C.s., Consultant Thoracic Surgeon
They discussed among other aspects the differences between slow progress, apparent spontaneous regression, spontaneous cure of a primary, and cure after incomplete excision or other inedequate therapy from which a cure was not to be expected. Boyd (1966) described two further cases of spontaneous regression of primary lung cancer.

In our experience neither spontaneous cure nor spontaneous regression has been observed, though delayed progress of an untreated primary and slow progression after incomplete resection are not unusual. A number of patients in both these groups have survived more than five years but have died from extension of the cancer after maximal survival of eight years. Cure as opposed to regression or delayed progress after incomplete surgery is a rarity in cancer in any site. Biopsy confirmation, a record of incomplete surgery, and necropsy confirmation of the absence of cancer throughout the body must be included among the criteria for acceptance. Fullerton and Hill (1963) described the case of a patient from whom a carcinoma of the stomach was incompletely resected in 1947. The patient died in 1963 and at necropsy no cancer was found. No other explanation than cure from incomplete surgery is possible. The extreme rarity of this event demands that claimed cases are fully reported and the data closely scrutinized.

Since 1951 incomplete resection has been considered the best available procedure if total removal of all macroscopic cancer was not possible. The early results were reported (Abbey Smith, 1957). Between 1951 and 196179 out of 450 resections were incomplete. At the conclusion of the operation on seven patients residual cancer remained on the wall of the atrium only-three have been cured by this procedure 
and are now reported and four died from metastases. In the other 72 the residual tumour remained on some other structure in addition to the atrial wall or in the chest wall, inaccessible lymph nodes, stump of a sutured pulmonary artery, or in the bronchial stump. Death was inevitably caused by local, metastatic, or combined extension of the residual cancer. The rate of progress was unpredictable. There appears, therefore, to be evidence of a striking difference between the course of residual cancer on the wall of the atrium and its course in or on other intrathoracic structures. This may have an importance beyond the fact of cure of three apparently incurable lesions.

\section{Patients}

Preoperative and postoperative details of the three patients are given (Tables I and II). The following features were common to each: all were males of introverted personality without significant family history, clinical evidence of abnormal endocrine activity, allergic disease, or known exposure to carcinogens other than cigarette tobacco.

At operation involvement of the left atrial wall by tumour growth along the wall of the pulmonary vein prevented total removal. A Brock mitral clamp was placed across the atrium, tumour being present on both atrial and pulmonary sides of the clamp. In Case 2 (Table I) two clamps were needed because of the width of atrial wall involvement. The clamps were placed as the last step of the operation and remained in place for no more than 15 minutes. A scalpel cut was made through the growth and atrial wall to free the lung. Diathermy was not used. About 10 interrupted sutures of No. 60 linen thread were placed through the atrial wall and tumour before removing the clamp (now a strong ligature was placed around the clamp and tightened as the clamp was removed in order to damage the blood supply of any residual growth). The endocardium did not appear to have penetrated by the tumour. The extent of the residual growth was difficult to measure; by volume it was about one-eighth of the original tumour. Examination of the lung showed the tumour to have been sliced through adjacent to the junction of the pulmonary veins. Extensive residual involvement of the atrial wall only was evident; all other mediastinal surfaces were free of tumour. The sutured atrial wall was not covered with any foreign material and the pericardial defect was not closed. An extensive hilar node dissection was not undertaken. Each of the tumours was under $5 \mathrm{~cm}$ in diameter and felt scirrhous. Apart from their non-curative features, the operations were entirely routine procedures.

After operation blood transfusion was less than 5 pints (2.8 litres) for each patient; the pneumonectomy space was treated routinely and injected with penicillin solution only. No cytotoxic drugs or radiotherapy were given. No postoperative changes in habits or environment occurred. All were unusually unwilling to attend follow-up. The relatives and the patient's doctor were told of the impossibility of cure. No serious attempt was made to reduce the drugs and alcohol intake in Case 2 for this reason. Two patients (Cases 1 and 2) knew they had lung cancer, but none knew the prognosis. After discharge from hospital the E.C.G. showed no abnormality.

\section{Summary of Necropsy Reports}

Case 1 (Dr. Way, 29 September 1970).-No carcinoma was found throughout the body. The left pleura was replaced by fibrous tissue. The left lung had been removed. The right lung was expanded and grossly oedematous (weight $1,230 \mathrm{~g}$ ) but not notably pneumonic. Carcinoma was not seen in the pericardium or in the

TABLE I-Preoperative Details

\begin{tabular}{|c|c|c|c|c|c|c|c|c|c|c|c|c|}
\hline $\begin{array}{l}\text { Case } \\
\text { No. }\end{array}$ & $\left|\begin{array}{c}\text { Age at } \\
\text { Opera- } \\
\text { tion }\end{array}\right|$ & $\begin{array}{c}\text { First } \\
\text { Symptom }\end{array}$ & $\begin{array}{l}\text { Bronch- } \\
\text { oscopy }\end{array}$ & $\begin{array}{c}\text { Date of } \\
\text { Operation }\end{array}$ & $\underset{\text { tion }}{\text { Opera- }}$ & $\begin{array}{c}\text { Site of Residual } \\
\text { Tumour on } \\
\text { Left Atrium }\end{array}$ & Cell Type & $\begin{array}{l}\text { Previous } \\
\text { Illnesses }\end{array}$ & Smoking & Occupation & $\begin{array}{l}\text { Blood } \\
\text { Group }\end{array}$ & $\begin{array}{l}\text { Carcinoma } \\
\text { in Primary } \\
\text { Relatives }\end{array}$ \\
\hline 1 & 59 & $\begin{array}{l}\text { Left } \\
\text { pleural } \\
\text { pain }\end{array}$ & $\begin{array}{l}\text { Not } \\
\text { visible }\end{array}$ & $\begin{array}{l}\text { January } \\
1955\end{array}$ & L.P. & $\begin{array}{l}\text { On atrium close } \\
\text { to origin of } \\
\text { left superior } \\
\text { pulmonary vein }\end{array}$ & Squamous & $\begin{array}{l}\text { 1916: Gunshot } \\
\text { wound/chest. } \\
\text { 1947: Partial } \\
\text { gastrectomy } \\
\text { for duodenal } \\
\text { ulcer }\end{array}$ & $\begin{array}{l}15 \text { cigs. } \\
\text { daily for } \\
46 \text { years }\end{array}$ & $\begin{array}{l}\text { Nail maker } \\
\text { (50 years) }\end{array}$ & $\mathrm{ORh}+$ & No \\
\hline 2 & 56 & $\begin{array}{l}\text { Haem- } \\
\text { optysis }\end{array}$ & Visible & $\begin{array}{l}\text { November } \\
1956\end{array}$ & L.P. & $\begin{array}{l}\text { Encircling } \\
\text { incised atrium }\end{array}$ & $\begin{array}{l}\text { Oat and } \\
\text { squamous }\end{array}$ & $\begin{array}{l}\text { Varicose } \\
\text { ulcers for } \\
20 \text { years }\end{array}$ & $\begin{array}{l}30 \text { cigs. } \\
\text { daily for } \\
40 \text { years }\end{array}$ & $\begin{array}{l}\text { Serving } \\
\text { Officer }\end{array}$ & $\begin{array}{l}\mathbf{A B} \\
\mathbf{R h}+\end{array}$ & No \\
\hline 3 & 43 & $\begin{array}{l}\text { Right } \\
\text { pleural } \\
\text { pain }\end{array}$ & $\begin{array}{l}\text { Not } \\
\text { visible }\end{array}$ & $\begin{array}{l}\text { December } \\
1959\end{array}$ & R.P. & $\begin{array}{l}\text { Encircling } \\
\text { incised atrium }\end{array}$ & Squamous & None & $\begin{array}{l}20 \text { cigs. } \\
\text { daily for } \\
29 \text { years }\end{array}$ & $\begin{array}{l}\text { Fettler in } \\
\text { iron foundry } \\
(20 \text { years })\end{array}$ & $\mathrm{ORh}+$ & Yes \\
\hline
\end{tabular}

L.P. $=$ Left penumonectomy. R.P. $=$ Right pneumonectomy

TABLE II-Postoperative details

\begin{tabular}{|c|c|c|c|c|c|c|c|c|c|c|}
\hline $\begin{array}{l}\text { Case } \\
\text { No. }\end{array}$ & $\begin{array}{l}\text { Complications } \\
\text { in } \\
\text { Convalescence }\end{array}$ & $\begin{array}{c}\text { Days in } \\
\text { Hospital after } \\
\text { Operation }\end{array}$ & Drugs & Illnesses & Smoking & Work & $\begin{array}{l}\text { Date of } \\
\text { Death }\end{array}$ & $\begin{array}{c}\text { Cause of } \\
\text { Death }\end{array}$ & $\begin{array}{c}\text { Length of } \\
\text { Survival } \\
\text { (years) }\end{array}$ & Necropsy \\
\hline 1 & $\begin{array}{l}\text { Paroxysmal } \\
\text { tachycardia }\end{array}$ & 15 & $\begin{array}{l}\text { Digoxin; anti- } \\
\text { biotics during } \\
\text { operation and } \\
\text { subsequently }\end{array}$ & $\begin{array}{l}\text { 1964: Prostatec- } \\
\text { tomy. 1965: } \\
\text { Vesicocolic } \\
\text { fistula and } \\
\text { diverticulitis. } \\
\text { Colostomy. } \\
\text { Mental depres- } \\
\text { sion last } \\
10 \text { years }\end{array}$ & $\begin{array}{l}\text { Continued as } \\
\text { before } \\
\text { operation }\end{array}$ & $\begin{array}{l}\text { Occasional } \\
\text { light manual } \\
\text { work }\end{array}$ & $\begin{array}{c}\text { September } \\
1970\end{array}$ & $\begin{array}{l}\text { Right heart } \\
\text { failure }\end{array}$ & 15 & Yes \\
\hline 2 & None & 16 & $\begin{array}{l}\text { Whisky, } 4 \text { bottles } \\
\text { each week. } \\
\text { Physeptone } \\
5 \text { mg daily for } \\
7 \text { years. } \\
\text { Drinamyl } \\
\text { intermittently }\end{array}$ & $\begin{array}{l}\text { Unexplained } \\
\text { swelling of } \\
\text { joints in } 1958\end{array}$ & $\begin{array}{l}\text { Continued } \\
\text { as before } \\
\text { operation }\end{array}$ & $\begin{array}{l}\text { Part-time } \\
\text { clerical } \\
\text { work }\end{array}$ & $\begin{array}{l}\text { December } \\
1963\end{array}$ & Pneumonia & 7 & Yes \\
\hline 3 & None & 20 & $\begin{array}{c}\text { Antibiotics } \\
\text { during } \\
\text { operation }\end{array}$ & None & $\begin{array}{l}\text { Reduced to } 12 \\
\text { cigs. daily }\end{array}$ & $\begin{array}{l}\text { Cellulose } \\
\text { painter } \\
\text { full-time } \\
\text { operation }\end{array}$ & Alive & - & 11 & - \\
\hline
\end{tabular}


wall of the left atrium. There was pronounced right-sided enlargement of the heart (weight $560 \mathrm{~g}$ ). Apart from the presence of the colostomy and the vesicocolic fistula there were no other notable findings in any other organ. Death was due to pulmonary oedema and right-sided heart failure.

Case 2 (Dr. Barrowcliff, 27 December 1963).-No carcinoma found throughout the body. The right lung was enlarged and uniformly firm with bronchopneumonia. Pus filled the right bronchi and trachea. The mediastinal pleura showed extensive calcification. The pericardium was adherent to the epicardium. The left atrium was identified as well as the site of suture. No tumour was found in this area or elsewhere in the mediastinum. Death was due to bronchopneumonia. Microscopical examination showed chronic pancreatitis and severe fatty degeneration of the liver. No trace of carcinoma was found in several blocks of the site of the residual tumour on the atrium, in the calcified mediastinal pleura, in the suprarenals, in local, cervical, para-aortic, supraclavicular, or porta hepatis lymph nodes, or in bone marrow $(\times 2)$, kidney, lung, liver, brain, and spleen.

In January 1971 the original sections were reviewed by a number of pathologists not concerned with the earlier reports on the sections. They reported:

Case 1.-Three sections were available, two of lung and one of lymph node. Those of the lung showed a moderately differentiated squamous-celled carcinoma of the lung. Keratinization was present but was not abundant. It enveloped bronchial cartilage, invaded lung parenchyma, and was seen partially to invade but not to penetrate the wall of a large pulmonary artery. The lymph node received separately showed no evidence of secondary deposit.

Case 2.-Seven sections were available, five of lung and two of lymph node. The tumour consisted of sheets of undifferentiated round cells with some features of oat-cell carcinoma. In very few areas attempted differentiation into transitional or squamous-celled carcinoma was seen. The sheets were intersected by a few broad bands of connective tissue. Infiltration and replacement of bronchial glands and lung parenchyma were seen. Mitotic figures were found with relative ease.

Case 3.-Three sections were available. The tumour was a squamous-celled carcinoma; in places it was solid and in places it was adenoid and formed small pseudo-acini from the degeneration of cell nests. It enveloped and in places invaded bronchial glands, bronchial cartilage, and lymphoid tissue. Mitotic figures were found without difficulty. Precise origin from bronchial mucosa was not seen.

\section{Discussion}

As Case 3 has survived more than four years longer than the next longest survivor from non-curative resection (an eight-year survivor with residual cancer in the bronchial stump), cure of the original cancer is assumed in this patient and confirmed by necropsy in the other two. No satisfactory explanation is available. Among the general factors which may be of importance in causing the spontaneous regression of cancer, Everson and Cole (1966) included the following: endocrine influences, fever and infection, allergic or immune reaction, interference with the nutrition of the cancer, removal of the carcinogenic agent, unusual sensitivity to usually inadequate therapy, complete surgical removal of the cancer, and incorrect histological diagnosis of malignancy. To this list we add the localization of residual cancer to tissue inimical to tumour growth-namely, the wall of the atrium. The outstanding feature, in looking back, is that death of the residual cancer had occurred only when residual tumour has remained in the wall of the atrium, while growth has continued if it is left on any other intrathoracic structures, as in the other 72 patients.

Direct spread of lung cancer to the heart is uncommon, primary heart tumours are rare, and metastasis to the heart from any cancer is unusual. For these reasons it is difficult to understand why the cancer in the three cases under discussion grew into the atrial wall if this is poor soil. The tumour might be expected to grow where it is most likely to prosper. Similar tumours should follow similar lines of least resistance as they extend through the lungs and media- stinum if the host invariably failed to modify or control growth. There is, however, no uniformity about the direction of growth of lung cancer. The lung affected by pneumoconiosis is also considered unfavourable tissue for cancer growth (Abbey Smith, 1959). This belief is strengthened by the study of our 10-year survivors from surgery; over $25 \%$ of 10-year survivors give a history of underground coalmining, whereas less than $5 \%$ of the total operated on gave the same history. An unfavourable environment seems to delay cancer growth, though clear differences exist between a cancer originating in a supposedly unfavourable environment (the pneumoconiotic lung) and one which grows from normal lung solely in the direction of a less favoured site (the atrium of the heart). Hadfield (1954) stated that there was no reliable information regarding environmental factors responsible for mitotic arrest.

There is no doubt that surgical removal was incomplete and that the histological diagnosis of malignancy was correct in these patients. As regards the other factors discussed by Everson and Cole (1966), there was no clinical evidence of their importance, except the possibility of interference with the nutrition of the tumour. These authors quote Rohdenburg's (1918) statement "that during an incomplete removal of cancer, the blood supply of the remaining tumour may be so impaired that death of the residual tumour occurs." It seems unlikely that cutting through tumour could devascularize the atrial portion, or that the surgical technique was responsible. The residual tumour, herniated through the pericardial defect, lay in the mediastinum and should acquire a blood supply. Apparently effective measures to impair the blood supply of residual chest wall cancer by extensive diathermy or on the pulmonary artery stump by mass ligation have always failed to arrest growth. The concept of being able to destroy the blood supply of a tumour in the atrial wall is unrealistic.

It is possible, with further experience, that cure may be achieved by resection with tumour remaining on some other intrathoracic organ than the atrium, though this seems most unlikely, at any rate, without additional therapy. Should this happen it would emphasize the importance of removing the bulk of the tumour and reduce the significance of the anatomical site of the residuum.

Discussing the immunotherapy of cancer, over a much wider field than lung cancer, both Alexander (1970) and Woodruff (1970) emphasized the necessity of removing as much of the tumour as possible by surgery or other means if immunotherapy is to be of value.

The evidence suggests that some metabolic or other property of the atrial wall may be the dominant factor in destroying residual cancer. Defining this property is a problem for the experimental laboratory.

I am indebted to Dr. D. F. Barrowcliff, Dr. M. K. Alexander, and Dr. K. J. Holley, of the Central Pathological Laboratory, Warwick, for their review of the histology; to Dr. Barrowcliff and Dr. S. P. B. Way, of Wordsley Hospital, for their permission to summarize their necropsy reports; and to Dr. Dermott Grene, of Warwick, and Dr. V. C. Hassan, of Halesowen, for their help.

\section{References}

Alexander, P. (1970). British Medical fournal, 4, 484

Bell, J. W., Jesseph, J. E., and Leighton, R. S. (1964). Fournal of Thoracic and Cardiovascular Surgery, 48, 984.

Blades, B., and McCorkle, R. G., jun. (1954). Fournal of Thoracic Surgery, 27,415 .

Boyd, W. (1966). Spontaneous Regression of Cancer. Springfield, Illinois,
Thomas.

Everson, T. C., and Cole, W. H. (1966). Spontaneous Regression of Cancer. London, Saunders

Fullerton, J. M., and Hill, R. D. (1963). British Medical fournal, 2, 1589. Hadfield, G. (1954). British Medical fournal, 2, 607.

Rohdenburg, G. L. (1918). Fournal of Cancer Research, 3, 193.

Smith, R. Abbey (1957). Thorax, 12, 79.

Smith, R. Abbey (1959). British fournal of Industrial Medicine,

Woodruff, Sir Michael (1970). British Medical Journal, 4, 486. 16, 318. 